\title{
Parental Communication and Life Satisfaction in Adolescence
}

\author{
María-Jesús Cava (1), Sofía Buelga (1) and Gonzalo Musitu (2) \\ (1) Universidad de Valencia (Spain) \\ (2) Universidad Pablo de Olavide (Spain)
}

\begin{abstract}
This study aims to analyze the influence of communication with the mother and father on adolescents' life satisfaction, as well as possible indirect effects through self-esteem, feelings of loneliness, and perceived classroom environment. These relationships, and possible gender differences, were analyzed in a sample of 1,795 adolescents $(52 \%$ male, $48 \%$ female) aged 11 to 18 years-old $(M=14.2, S D=1.68)$, using structural equation modeling. Results indicate a direct effect of communication-mother (girls: $\beta=.19, p<.001$; boys: $\beta=.16, p<.05$ ) and communication-father (girls: $\beta=.22, p<.001$; boys: $\beta=.17, p<.05$ ) on adolescent life satisfaction; and also indirect effects through self-esteem (communication-mother: girls, $\beta=.18, p<.01$; boys: $\beta=.19, p<.05$; communication-father: girls: $\beta=.28, p<.001$; boys: $\beta=.27, p<.01)$ and feelings of loneliness (communication-mother: girls: $\beta=-.19, p<.01$; boys: $\beta=-.21, p<.05$; communication-father: girls: $\beta=-.31, p<.001$; boys: $\beta=-.20, p<.01)$. The results and implications of this study are discussed.
\end{abstract}

Keywords: family, communication, life satisfaction, adolescence.

Most adolescence research has focused on analyzing the difficulties in adapting to the changes associated with this developmental stage, and on risk factors for engaging in problem behaviors (Koepke \& Denissen, 2012; Stautz \& Cooper, 2013). However, a growing number of studies attempt to analyze not only what elements lead to difficulties in psychosocial adjustment, but also what resources and competencies can foster adolescents' positive, healthy development (Diener \& Diener, 1995; Lerner, 2002; Theokas \& Lerner, 2006). The Positive Psychology framework has explored what aspects can improve the psycho- logical well-being and mental health of this population, with the goal of increasing their levels of healthy development (Diener \& Diener, 1995; Kong \& You, 2013; Oberle, Schonert-Reichl, \& Zumbo, 2011). The analysis of these factors makes it possible to not only prevent psychosocial problems from developing, but also to increase adolescents' quality of life and well-being. Thus, this is an area of particular interest.

From this point of view, life satisfaction is a fundamental construct due to its relationship with numerous positive personal and social variables (Oberle et al., 2011). Life satisfaction refers to an individual's judgment of his/her overall quality of life based on his/ her own criteria, and it is a basic cognitive component of subjective well-being (Proctor, Linley, \& Maltby, 2009). Therefore, there has been a considerable increase in the number of life satisfaction studies conducted in adult populations, and more recently in adolescents (Oberle et al., 2011). Although fewer studies have been carried out with adolescents, research on life satisfaction is especially useful at this stage of development due to its relationship with certain indicators of appropriate psychosocial development, such as social adjustment, mental health, and academic achievement (Proctor et al., 2009). During adolescence, life satisfaction is positively related to self-esteem, parental support, and a positive perception of the class- room environment, and negatively related to symptoms of depression, anxiety, stress, aggressive behavior, and negative attitudes about school and teachers (Bendayan, Blanca, Fernández-Baena, Escobar, \& Trianes, 2013; Martínez-Antón, Buelga, \& Cava, 2007; Valois, Zullig, Huebner, \& Drane, 2009).

Previous studies have also confirmed the importance of family environment (Ma \& Huebner, 2008; Proctor et al., 2009). As Proctor et al. (2009) point out, perceived support from parents and friends is essential to adolescents' mental health. Moreover, Ma and Huebner (2008) argue that for young people, adequate bonding with parents contributes to positive development and subjective well-being even more than peer bonding does. The family environment, in addition to providing direct support, helps adolescents develop resources and competencies they can later use in other social contexts. With this in mind, and given that life satisfaction is a central construct within Positive Psychology and has been analyzed very little in adolescent populations, it would be of great interest to more closely examine the role of the parent-child relationship in life satisfaction.

Parent-child communication is an underexamined family variable in this area. Past studies have linked it to behavioral problems in adolescence, suggesting that poor communication is a risk factor for problem behaviors (Varela, Ávila, \& Martínez, 2013). However, the role of adequate communication in enhancing adolescents' life 
satisfaction has scarcely been examined. In one of the few studies addressing this question, Levin, Dallago, and Currie (2012) reported that the quality of family communication had a greater impact than family structure or financial resources on adolescent life satisfaction. These results have been found in both boys and girls, and regarding communication with both mother and father (Levin et al., 2012), but some studies have concluded that the father- adolescent relationship is especially important (Proctor et al., 2009). It is crucial to distinguish between communication with mother and father given that adolescent boys and girls display a different pattern of communication with each parent (Parra \& Oliva, 2002), which may affect life satisfaction differently.

Furthermore, parental communication may affect adolescent life satisfaction indirectly. Good communication could increase adolescents' self-esteem and decrease feelings of loneliness, as they would feel closer, more valued, and better understood by their parents. Although friends are also important during adolescence, previous studies have shown the influence of the family on adolescents' self-esteem and feelings of loneliness (Cava, Musitu, Buelga, \& Murgui, 2010), and both self-esteem and feelings of loneliness are closely related to life satisfaction (Kong \& You, 2013; Martínez-Antón et al., 2007; Proctor et al., 2009). Therefore, it would be advisable to analyze these relationships in adolescents, as well as any possible differences between boys and girls.

The classroom environment also appears to be related to adolescents' life satisfaction, particularly their relationships with teachers and classmates. Previous studies have found an association between adolescents' positive perceptions of the classroom environment and higher life satisfaction, fewer feelings of loneliness, and higher self-esteem (Martínez-Antón et al., 2007; Oberle et al., 2011). The classroom environment depends largely on the way students perceive the quality of the student-teacher relationship and relations among students (Cava et al., 2010). Adolescents who have good family communication can implement similar patterns of communication with teachers and classmates, improving their interpersonal relationships in the school context so they perceive a more positive school climate. This more positive perception of the classroom environment and interpersonal relationships at school could also reduce feelings of loneliness by promoting feelings of belonging and self-esteem.

This study's main goal, therefore, is to analyze the relationship between communication with mother and father - separately - and adolescent life satisfaction. Structural equation modeling will be used to analyze the possible direct effects of parental communication on life satisfaction, as well as its possible indirect effects via self-esteem, feelings of loneliness, and perceived classroom environment. The proposed model (Figure 1) will analyze boys and girls separately. It is hypothesized that life satisfaction will be higher in adolescent boys and girls who communicate more positively with their mothers and fathers. Positive communication will also be associated with higher self-esteem, fewer feelings of loneliness, and a more positive perception of the classroom environment in adolescents, variables which are directly related to higher life satisfaction.

\section{Method}

\section{Participants}

A total of 1,795 adolescent boys and girls ( $52 \%$ and $48 \%$, respectively) participated in this study. They ranged in age from 11 to 18 years old $(M=14.2, S D=1.68)$ and included ESO (compulsory secondary education) and bachillerato (final 2 years of high school, elective) students from 9 different schools in the Spanish region of Andalucía. Participants were selected through stratified cluster sampling (Santos, Muñoz, Juez, \& Cortiñas, 2003). The sample included public and private schools in urban and rural areas of Andalucía. Strata were established by grade (ESO 1, 2, 3, and 4, and bachillerato 1 and 2). The adolescents' families had a moderate socioeducational level and mostly included father, mother, and children (83.5\%). Some participants, however, lived only with their mother $(11.5 \%)$, only with their father $(2.1 \%)$, or alternately with their mother and father $(2.9 \%)$.

\section{Instruments}

Barnes and Olson's (1982) Parent-adolescent Communication Scale was utilized to measure communication with mother and father (Spanish adaptation by Estévez, 


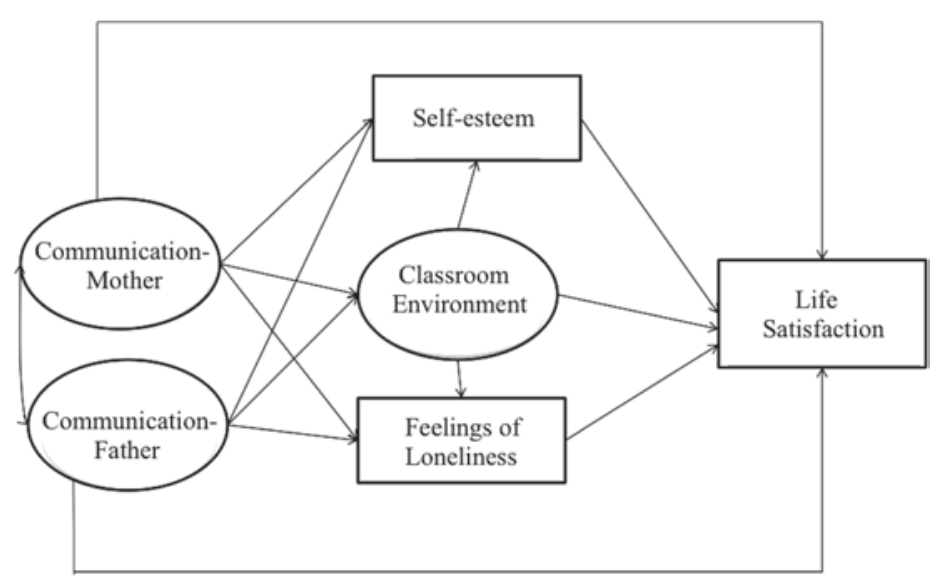

Figure 1. Proposed theoretical model to empirically test for direct and indirect effects of communication with mother and father on life satisfaction.

Herrero, \& Musitu, 2005). This 20-item scale has response options ranging from 1 (never) to 5 (always), and it has two subscales: communication with mother, and communication with father. Each subscale includes three dimensions: Openness in Family Communication, that is, ease of parent-child communication (e.g., "I can discuss my beliefs with my mother/father without feeling restrained or embarrassed [Puedo hablarle acerca de lo que pienso sin sentirme mal o incómodo/a]); Offensive Communication with Parents, which refers to difficult communication that may cause hurt feelings ("S/he insults me when $\mathrm{s} / \mathrm{he}$ is angry with me" [Me dice cosas que me hacen daño]); and Avoidant Communication with Parents, in other words, lack of communication ("There are topics I avoid discussing with him/her" [Hay temas de los que prefiero no hablarle]). Earlier research in Spanish adolescents yielded acceptable reliability indices, between .64 and .91 (Cava, Murgui, \& Musitu, 2008; Estévez et al., 2005). This study obtained a Cronbach's alpha of .86 on the communication with mother and communication with father subscales.

Self-esteem was measured by the Rosenberg Self- esteem Scale (1989; Spanish adaptation by Martín-Albo, Núñez, Navarro, \& Grijalvo, 2007), a widely used assessment of overall self-esteem with adequate psychometric properties. Respondents answer its 10 items (e.g., "I feel that I have a number of good qualities" [Creo que tengo numerosas cualidades positivas]) on a scale from 1 (strongly disagree) to 4 (strongly agree). In the present study, its internal consistency with Cronbach's alpha was .76.

The UCLA Loneliness Scale (Russell, 1996; Spanish adaptation by Expósito \& Moya, 1999) was used to measure adolescent loneliness. It consists of 20 items (e.g. "How often do you feel that you lack companionship?" [¿Con qué frecuencia sientes que te falta compañia?]) that evaluate feelings of loneliness on a scale from 1 (never) to 4 (always). This scale is widely used and has shown adequate psychometric properties. Its Cronbach's alpha in this study was .89 .

To measure the perceived classroom environment, the Relationship dimension of the Classroom Environment Scale by Moos and Trickett (1973; Spanish adaptation by Fernández-Ballesteros \& Sierra, 1989) was utilized. This dimension includes 30 true- false items grouped into 3 subscales containing 10 items each: Involvement, Affiliation, and Teacher Support. The Involvement subscale measures the extent to which students perceive themselves as engaged and participating (e.g., "Students put a lot of energy into what they do here" [Los alumnos ponen mucho interés en lo que hacen en esta clase]). The Affiliation subscale measures how much friendship and unity respondents perceive among classmates ("Students in this class get to know each other really well" [En esta clase, los alumnos llegan a conocerse realmente bien unos a otros]). Finally, the Teacher Support subscale measures how supportive, concerned, and friendly the students perceive their teacher to be ("This teacher spends very little time just talking with students" [Este profesor dedica muy poco tiempo a hablar con los alumnos]). In this study, a Cronbach's alpha coefficient of .63 was found for the Involvement and Affiliation subscales, and .68 for Teacher Support.

Finally, life satisfaction was assessed using the Satisfaction with Life Scale by Diener, Emmons, Larsen, and Griffin (1985; Spanish adaptation by Atienza, Pons, Balaguer, \& García-Merita, 2000). This 5-item instrument provides an index of overall life satisfaction with regard to the subjective well-being perceived by adolescents (e.g., "In most ways my life is close to my ideal" [Mi vida es en la mayoría de los aspectos como me gustaría que fuera]). Responses are given on a scale from 1 (strongly disagree) to 4 (strongly agree). The Cronbach's alpha coefficient to measure reliability was .74 


\section{Procedure}

After selecting schools to participate in the study, the research team met with teachers to explain the research objectives. They also requested parental permission by sending an informational letter home with the adolescents. Once all of the necessary informed con- sent forms had been signed, investigators previously trained in applying the instruments administered them in the students' usual classrooms. They also informed participants that their responses would be kept confidential, and that they could drop out of the study at any time. No student opted out of participating. This study adhered to all the ethics guidelines governing research with human subjects, and it upheld the fundamental principles of the Declaration of Helsinki, its revisions, and its established guidelines (informed consent, right to access information, protection of personal information, guaranteed confidentiality, non-discrimination, and right to withdraw participation at any time freely and without reprisal).

\section{Data Analysis}

First, Pearson correlations were computed between all the variables, and means were calculated as a function of sex. Next, structural equation modeling was carried out using the EQS 6.0 program (Bentler, 1995) to analyze relationships between variables in boys as well as girls. Since the data deviated from multivariate normal distribution, robust estimators were used to determine the model's goodness of fit to the data, and whether or not these goodness of fit coefficients were statistically significant. Since it is not advisable to test a model's overall goodness of fit with only one index, various indices were calculated.

\section{Results}

Table 1 shows that the majority of the correlations among variables were significant. Life satisfaction was significantly correlated with all the other variables, with an especially high negative correlation with feelings of loneliness, $r=-.49, p<.01$, girls; $r=-.49, p<.01$, boys; and high positive correlations with self-esteem, $r=.46, p<$ .01 , girls; $r=.44, p<.01$, boys; openness in communication with mother, $r=.34, p<.01$, girls; $r=.41, p<.01$, boys; and openness in communication with father, $r=.37, p<.01$, girls; $r=.36, p<.01$, boys. A similar pattern of correlations was observed in boys and girls, with few significant differences between the means on these variables according to sex. However, girls reported more openness in communication with their mothers, and boys with their fathers, and girls perceived greater affiliation and teacher support.

Subsequently, the hypothesized model was analyzed for boys and girls separately. In both cases, three latent variables were examined: Communication- Mother (latent factor consisting of the following three indicators: openness in communication with mother; avoidant communication with mother; and offensive communication with mother); Communication-Father (consisting of: openness in communication with father; avoidant communication with father; and offensive communication with father); and Classroom Environment (consisting of: involvement, affiliation, and teacher support). The indicators openness in communication with mother, openness in communication with father, and involvement were set at 1during estimation. The correlation between the Communication- Mother and Communication-Father factors in the model was .74, $p<.001$ in boys and .52, $p<.001$ in girls. Since the data lacked multivariate normal distribution (Mardia's coefficient = 65.7331 in boys; 53.5662 in girls), maximum-likelihood estimation was applied using robust estimators. The hypothesized model fit both the boys' and the girls' data well: S-B $\chi^{2}=118.06, d f=40, p<.001$, CFI $=.97$, RMSEA = .04 (.03-.05) for boys; S-B $\chi^{2}=65.22, d f=42, p<.001$, CFI $=.99$, RMSEA = .02 (.01-.03) for girls. The model explained $37.4 \%$ of the variance in Life Satisfaction in boys, and $39 \%$ in girls.

Figure 2 shows the structural model analyzed, as well as standardized coefficients and their respective probabilities. The results suggest a direct, positive, significant effect of communication-mother, girls: $\beta=.19, p$ $<.001$; boys: $\beta=.16, p<.05$, and communication-father, girls: $\beta=.22, p<.001$; boys: $\beta=.17, p<.05$, on adolescent life satisfaction. Indirect effects were also observed, through the influence of communication with both parents, on self-esteem, perceived classroom environment, and feelings of loneliness. Communication-mother was positively related to self-esteem, girls: $\beta=.18, p<.01$; boys: $\beta=.19, p<.05$, and perceived classroom environment, girls: $\beta=$ $.25, p<.001$; boys: $\beta=.27, p<.01$, and negatively related to feelings of loneliness girls: $\beta=-.19, p<.01 ;$ boys: $\beta=-$ $.21, p<.05$; both variables are associated with life satisfaction. In girls and boys, self-esteem is positively related to life satisfaction, girls: $\beta=.16, p<.001$; boys: $\beta=.17, p<.001$, and negatively to feelings of loneliness, girls: $\beta=-$ $.21, p<.001$; boys: $\beta=-.20, p<.001$. The impact of perceived classroom environment, however, was smaller and only significant in girls, $\beta=.05, p<.05$. Communication-father was also positively related to self-esteem, girls: $\beta=.28, p$ $<.001$; boys: $\beta=.27, p<.01$, and classroom environment, girls: $\beta=.22, p<.01$; boys: $\beta=.43, p<.001$, and negatively to feelings of loneliness, girls: $\beta=-.31, p<.001$; boys: $\beta=-.20$, 
Table 1. Bivariate Correlations and Effect Size (Boys above the Diagonal), Means, and Standard Deviations for all Variables

\begin{tabular}{|c|c|c|c|c|c|c|c|c|c|c|c|c|}
\hline Variable & 1 & 2 & 3 & 4 & 5 & 6 & 7 & 8 & 9 & 10 & 11 & 12 \\
\hline 1. Openness in Communication (mother) & & $\begin{array}{r}-.31^{* *} \\
(.06)\end{array}$ & $\begin{array}{r}-12^{* *} \\
(.02)\end{array}$ & $\begin{array}{l}.62^{* *} \\
(1.6)\end{array}$ & $\begin{array}{r}-.21^{* *} \\
(.04)\end{array}$ & $\begin{array}{c}-.08^{* *} \\
(.01)\end{array}$ & $\begin{array}{l}.28^{* *} \\
(.06)\end{array}$ & $\begin{array}{l}.19 * * \\
(.04)\end{array}$ & $\begin{array}{l}.19^{* *} \\
(.04)\end{array}$ & $\begin{array}{l}.23^{* *} \\
(.04)\end{array}$ & $\begin{array}{r}-.32^{* *} \\
(.06)\end{array}$ & $\begin{array}{l}.41^{* *} \\
(.09)\end{array}$ \\
\hline 2. Offensive Communication (mother) & $\begin{array}{r}-.46^{* *} \\
(1.0)\end{array}$ & & $\begin{array}{l}.33^{* *} \\
(.07)\end{array}$ & $\begin{array}{r}-.22^{* *} \\
(.04)\end{array}$ & $\begin{array}{l}.75^{* *} \\
(2.0)\end{array}$ & $\begin{array}{l}.25^{* *} \\
(.05)\end{array}$ & $\begin{array}{r}-.23^{* *} \\
(.04)\end{array}$ & $\begin{array}{r}-.13^{* *} \\
(.02)\end{array}$ & $\begin{array}{r}-.27^{* *} \\
(.05)\end{array}$ & $\begin{array}{r}-.23^{* *} \\
(.04)\end{array}$ & $\begin{array}{l}.28^{* *} \\
(.06)\end{array}$ & $\begin{array}{r}-.24^{* *} \\
(.05)\end{array}$ \\
\hline 3. Avoidant Communication (mother) & $\begin{array}{c}-.28^{*} \\
(.06)\end{array}$ & $\begin{array}{l}.26^{* *} \\
(.05)\end{array}$ & & $\begin{array}{r}-.11^{* *} \\
(.02)\end{array}$ & $\begin{array}{l}.29^{* *} \\
(.06)\end{array}$ & $\begin{array}{l}.70^{* *} \\
(2.0)\end{array}$ & $\begin{array}{c}-.20^{* *} \\
(.04)\end{array}$ & -.03 & $\begin{array}{r}-.10^{* * *} \\
(.02)\end{array}$ & $\begin{array}{r}-.13^{* *} \\
(.02)\end{array}$ & $\begin{array}{l}.18^{* *} \\
(.03)\end{array}$ & $\begin{array}{r}-.10^{* *} \\
(.02)\end{array}$ \\
\hline 4. Openness in Communication (father) & $\begin{array}{l}.50^{* *} \\
(1.1)\end{array}$ & $\begin{array}{r}-.27^{* *} \\
(.05)\end{array}$ & $\begin{array}{r}-.16^{* *} \\
(.03)\end{array}$ & & $\begin{array}{r}-.30^{* *} \\
(.06)\end{array}$ & $\begin{array}{r}-.13^{* *} \\
(.02)\end{array}$ & $\begin{array}{l}.29^{* *} \\
(.06)\end{array}$ & $\begin{array}{l}.23^{* *} \\
(.04)\end{array}$ & $\begin{array}{l}.20^{* *} \\
(.04)\end{array}$ & $\begin{array}{l}.24^{* *} \\
(.05)\end{array}$ & $\begin{array}{r}-.33^{* *} \\
(.07)\end{array}$ & $\begin{array}{l}.36^{* *} \\
(.07)\end{array}$ \\
\hline 5. Offensive Communication (father) & $\begin{array}{r}-.21^{* *} \\
(.04)\end{array}$ & $\begin{array}{l}.60^{* *} \\
(1.5)\end{array}$ & $\begin{array}{l}.14^{* *} \\
(.03)\end{array}$ & $\begin{array}{c}-.46^{* *} \\
(1.0)\end{array}$ & & $\begin{array}{l}.35^{* *} \\
(.07)\end{array}$ & $\begin{array}{r}-.25^{* *} \\
(.05)\end{array}$ & $\begin{array}{c}-.14^{* *} \\
(.03)\end{array}$ & $\begin{array}{r}-.28^{* *} \\
(.06)\end{array}$ & $\begin{array}{r}-.26^{* *} \\
(.05)\end{array}$ & $\begin{array}{l}.29^{* *} \\
(.06)\end{array}$ & $\begin{array}{r}-.26^{* *} \\
(.05)\end{array}$ \\
\hline 6. Avoidant Communication (father) & $\begin{array}{r}-.12^{* *} \\
(.02)\end{array}$ & $\begin{array}{l}.22^{* *} \\
(.04)\end{array}$ & $\begin{array}{l}.59^{* *} \\
(1.4)\end{array}$ & $\begin{array}{r}-.25^{* *} \\
(.05)\end{array}$ & $\begin{array}{l}.33^{* *} \\
(.07)\end{array}$ & & $\begin{array}{c}-.21^{* *} \\
(.04)\end{array}$ & -.05 & $\begin{array}{r}-.11^{* *} \\
(.02)\end{array}$ & $\begin{array}{r}-.14^{* *} \\
(.03)\end{array}$ & $\begin{array}{l}.17^{* *} \\
(.03)\end{array}$ & $\begin{array}{r}-.14^{* *} \\
(.03)\end{array}$ \\
\hline 7. Self-esteem & $\begin{array}{l}.27^{* *} \\
(.05)\end{array}$ & $\begin{array}{r}-.20^{* *} \\
(.04)\end{array}$ & $\begin{array}{r}-.16^{* *} \\
(.03)\end{array}$ & $\begin{array}{l}.28^{* *} \\
(.06)\end{array}$ & $\begin{array}{r}-.25^{* *} \\
(.05)\end{array}$ & $\begin{array}{r}-.16^{* *} \\
(.03)\end{array}$ & & $\begin{array}{l}.11^{* *} \\
(.02)\end{array}$ & $\begin{array}{l}.19^{* *} \\
(.04)\end{array}$ & $\begin{array}{l}.11^{* *} \\
(.02)\end{array}$ & $\begin{array}{r}-.49^{* *} \\
(1.1)\end{array}$ & $\begin{array}{l}.44^{* *} \\
(1.0)\end{array}$ \\
\hline 8. Involvement (classroom environment) & $\begin{array}{l}.11^{* *} \\
(.02)\end{array}$ & $\begin{array}{c}-.14^{* *} \\
(.03)\end{array}$ & $\begin{array}{r}-.10^{* *} \\
(.02)\end{array}$ & $\begin{array}{l}.13^{* *} \\
(.02)\end{array}$ & $\begin{array}{c}-.10^{* *} \\
(.02)\end{array}$ & $\begin{array}{c}-.13^{* *} \\
(.02)\end{array}$ & $\begin{array}{l}.12^{* *} \\
(.02)\end{array}$ & & $\begin{array}{l}.35^{* *} \\
(.07)\end{array}$ & $\begin{array}{l}.24^{* *} \\
(.05)\end{array}$ & $\begin{array}{r}-.23^{* *} \\
(.04)\end{array}$ & $\begin{array}{l}.22^{* *} \\
(.04)\end{array}$ \\
\hline 9. Affiliation (classroom environment) & $\begin{array}{l}.16^{* *} \\
(.03)\end{array}$ & $\begin{array}{r}-.13^{* *} \\
(.02)\end{array}$ & $\begin{array}{r}-.11^{* *} \\
(.02)\end{array}$ & $\begin{array}{l}.20^{* *} \\
(.04)\end{array}$ & $\begin{array}{r}-.09 * * \\
(.01)\end{array}$ & $\begin{array}{c}-.09 * * \\
(.01)\end{array}$ & $\begin{array}{l}.20^{* *} \\
(.04)\end{array}$ & $\begin{array}{l}.47^{* *} \\
(1.0)\end{array}$ & & $\begin{array}{l}.32^{* *} \\
(.06)\end{array}$ & $\begin{array}{c}-.34^{* *} \\
(.07)\end{array}$ & $\begin{array}{l}.25^{* *} \\
(.05)\end{array}$ \\
\hline 10. Teacher Support (classroom environment) & $\begin{array}{l}.19^{* *} \\
(.04)\end{array}$ & $\begin{array}{r}-.18^{* *} \\
(.03)\end{array}$ & -.04 & $\begin{array}{l}.19^{* *} \\
(.04)\end{array}$ & $\begin{array}{r}-.16^{* *} \\
(.03)\end{array}$ & $\begin{array}{r}-.08^{*} \\
(.01)\end{array}$ & $\begin{array}{l}.18^{* *} \\
(.03)\end{array}$ & $\begin{array}{l}.33^{* *} \\
(.07)\end{array}$ & $\begin{array}{l}.29^{* *} \\
(.06)\end{array}$ & & $\begin{array}{r}-.19^{* *} \\
(.04)\end{array}$ & $\begin{array}{l}.24^{* *} \\
(.05)\end{array}$ \\
\hline 11. Feelings of Loneliness & $\begin{array}{r}-.32^{* *} \\
(.06)\end{array}$ & $\begin{array}{l}.23^{* *} \\
(.04)\end{array}$ & $\begin{array}{l}.13^{* *} \\
(.02)\end{array}$ & $\begin{array}{r}-.36^{* *} \\
(.07)\end{array}$ & $\begin{array}{l}.27^{* *} \\
(.05)\end{array}$ & $\begin{array}{l}.14^{* *} \\
(.03)\end{array}$ & $\begin{array}{r}-.54^{* *} \\
(1.3)\end{array}$ & $\begin{array}{r}-.16^{* *} \\
(.03)\end{array}$ & $\begin{array}{r}-.25^{* *} \\
(.05)\end{array}$ & $\begin{array}{r}-.16^{* *} \\
(.03)\end{array}$ & & $\begin{array}{r}-.49^{* *} \\
(1.1)\end{array}$ \\
\hline 12. Life Satisfaction & $\begin{array}{l}.34^{* *} \\
(.07)\end{array}$ & $\begin{array}{r}-.24^{* *} \\
(.05)\end{array}$ & $\begin{array}{r}-.15^{* *} \\
(.03)\end{array}$ & $\begin{array}{l}.37^{* *} \\
(.08)\end{array}$ & $\begin{array}{r}-.27^{* *} \\
(.05)\end{array}$ & $\begin{array}{r}-.19^{* *} \\
(.04)\end{array}$ & $\begin{array}{l}.46^{* *} \\
(1.0)\end{array}$ & $\begin{array}{l}.19^{* *} \\
(.04)\end{array}$ & $\begin{array}{l}.25^{* *} \\
(.05)\end{array}$ & $\begin{array}{l}.21^{* *} \\
(.04)\end{array}$ & $\begin{array}{r}-.49^{* *} \\
(1.1)\end{array}$ & \\
\hline$M$ boys & $3.93^{*}$ & 1.81 & 2.95 & $3.70^{* *}$ & 1.86 & 2.98 & 3.15 & 1.43 & $1.68^{*}$ & $1.66^{*}$ & 1.84 & 3.10 \\
\hline S.D. & .74 & .79 & .72 & .82 & .85 & .75 & .42 & .22 & .21 & .24 & .41 & .59 \\
\hline$M$ girls & $3.99^{*}$ & 1.80 & 2.93 & $3.55^{* *}$ & 1.83 & 3.05 & 3.11 & 1.42 & $1.70^{*}$ & $1.69^{*}$ & 1.81 & 3.12 \\
\hline S.D. & .73 & .73 & .70 & .83 & .78 & .72 & .44 & .22 & .21 & .23 & .42 & .60 \\
\hline
\end{tabular}

${ }^{* *} p<.01 ;{ }^{*} p<.05$. Large effect size $d>0.80$; medium $d>0.50$; and small $d>.20$ (Cohen, 1988). 


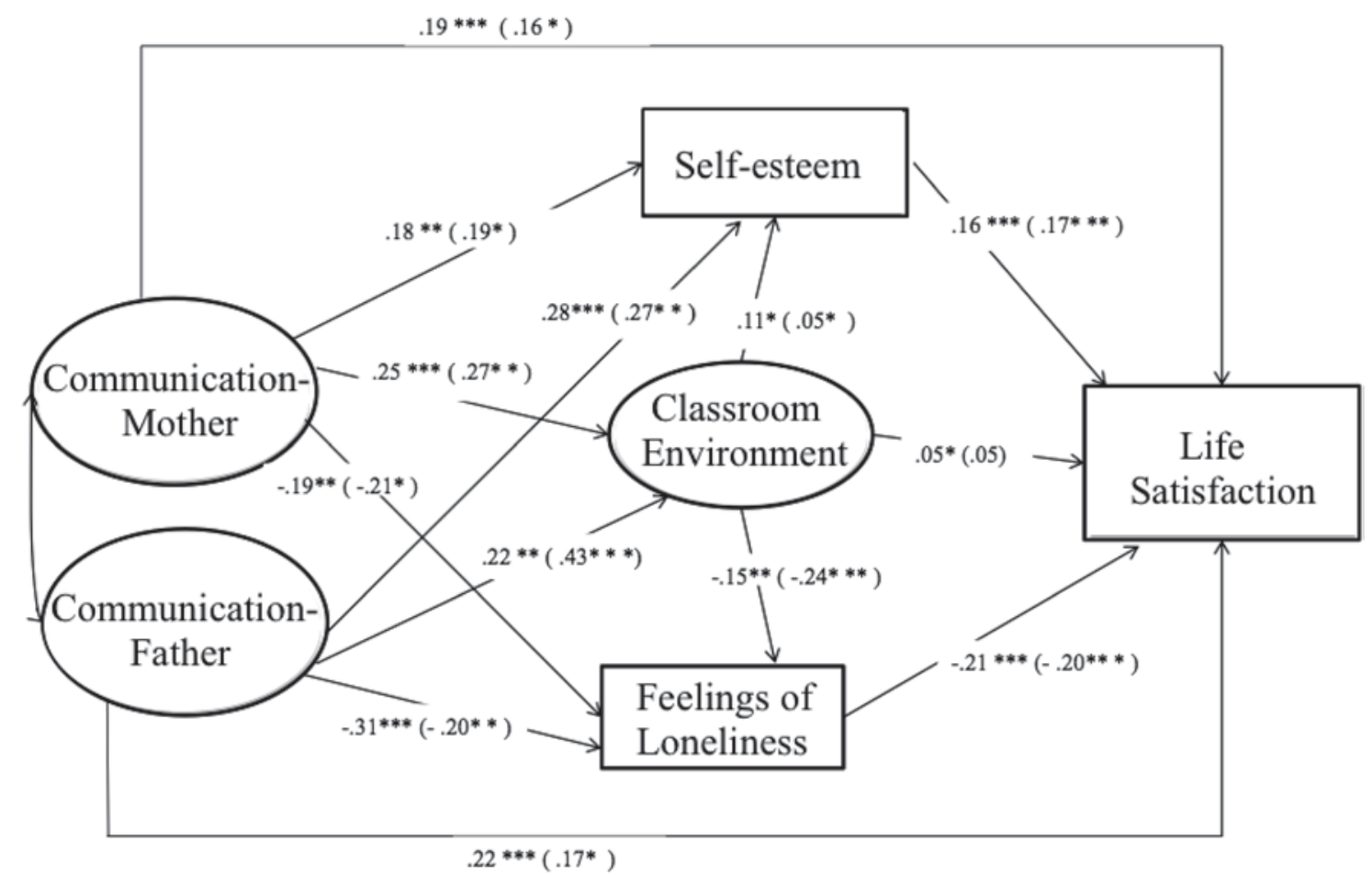

Figure 2. Final structural model with standardized coefficients and associated probabilities for girls (outside parentheses) and boys (in parentheses).

$p<.01$; these variables are directly related to life satisfaction.

\section{Discussion}

The purpose of this study was to examine the relationship between communication with the mother and father, separately, and adolescent life satisfaction. The data suggest that in both boys and girls, positive communication with both the mother and father is directly associated with higher life satisfaction. These results agree with the work of Levin et al. (2012). Therefore, adolescents who communicate well with their families probably place higher value on their ability to express their feelings and ideas openly and sincerely to their parents, and they may interpret this communication as an aspect of parental support, trust, and closeness. Although they might prefer to discuss certain topics with friends, they seem to value this positive parental communication highly. This was especially true of girls, for whom the influence of positive communication on life satisfaction was slightly higher, perhaps because of due to gender differences in cultural norms and socialization. Differences in parents' socialization styles based on the child's gender (Garaigordobil \& Aliri, 2012) could also explain why communication is more open between mothers and daughters, and between fathers and sons. Given these findings, future studies should explore gender differences in greater depth, as well as the role that adolescents' age might play in this relationship. Considering that parent-child communication evolves during adolescence (Parra \& Oliva, 2002) - different risk and protective factors apply during early and mid-adolescence (Cava et al., 2008) - it would be interesting to determine whether the influence of family communication on adolescent life satisfaction varies at different stages of adolescence.

Furthermore, these results reveal that positive family communication affects variables directly related to life satisfaction, such as self-esteem and feelings of loneliness. As a positive family environment favors children's well-being (Proctor et al., 2009), adequate communication with the father and mother is also an essential resource that helps adolescents develop their self-esteem. Better communication with parents may also involve greater perceived support, fewer feelings of loneliness, and the development of social skills and competencies that are useful to them in other contexts - such as the classroom- helping them to become better integrated at school and in their social lives (Estévez et al., 2005). Therefore, it is likely that through this positive family communication, adolescents develop a more favorable view of themselves and better communication skills, resulting in greater life satisfaction. Although both parents are important, communication with the father appears to be more relevant to self-esteem and feelings of loneliness in adolescent boys and girls, so the 
mother and father may play different roles. Furthermore, in boys, the influence of communication with the father seems especially significant in perceptions of the classroom environment. This greater impact may be related to the father's role in adolescents' developing attitudes toward rules and authority figures (Cava, Estévez, Buelga, \& Musitu, 2013). These attitudes begin at home and continue to evolve at school around the figure of the teacher and the class rules.

Moreover, while communication with both parents had an impact on adolescent boys' and girls' perceptions of the classroom environment, these perceptions only affected the life satisfaction of girls. Prior studies have related life satisfaction to a positive perception of the classroom environment in adolescents (Buelga, Musitu, Murgui, \& Pons, 2008; Oberle et al., 2011). In the present study, though, this effect was not significant in boys, perhaps because other variables were more important to them. The girls' more favorable perceptions of certain aspects of the classroom environment - perceived teacher support and friendship among classmates may explain this difference. However, the results might have been different had classroom environment been measured more comprehensively by also including sociometric measures and measures of academic achievement and school adjustment (as perceived by the teacher). Future studies of adolescent life satisfaction should explore those variables.

The present research has certain limitations. For example, the data were cross-sectional, and so we can only show the correlations between variables. Based on this information, we cannot reach any conclusions about causation; therefore, longitudinal research is needed. In addition, it would be advantageous to include parents' perceptions about how they communicate with their adolescent children. While it was imperative to find out the adolescents' perceptions of the family and school environments, gathering information from different sources would expand our under- standing of parent-child and teacher-student relations, and how to build relationships that encourage adolescent well-being and positive development. The final limitation of this study is that it did not determine whether these variables correlate differently at different stages of adolescence. Therefore, future research should test the same model in participants at different stages of adolescence.

In spite of its limitations, this study provides pertinent data about adolescent life satisfaction, gender differences, and how communication with the mother and father relates to life satisfaction. Research on positive adolescent development remains incipient. Studies have focused predominantly on problem behaviors rather than how to enhance well-being. Nevertheless, this new perspective could promote quality of life and healthy development in all adolescents by creating interventions that can develop their personal and social competencies and resources, and by fostering the variables involved in positive development (Lerner, 2002; Theokas \& Lerner, 2006).

\section{References}

Atienza F. L., Pons D., Balaguer I., \& García-Merita M. (2000). Propiedades psicométricas de la escala de satisfacción con la vida en adolescentes [Psychometric properties of the satisfaction with life scale in adolescents]. Psicothema, 12, 314-320.

Barnes H. L., \& Olson H. D. (1982). Parent-adolescent communication scale. In H. D. Olson (Ed.), Family inventories (pp. 33-48). St. Paul, MN: University of Minnesota.

Bendayan R., Blanca M. J., Fernández-Baena J. F., Escobar M., \& Trianes M. V. (2013). New empirical evidence on the validity of the satisfaction with life scale in early adolescents. European Journal of Psychological Assessment, 29, 36-43. http://dx.doi.org/10.1027/1015-5759/a000118

Bentler P. M. (1995). EQS structural equations program manual. Encino, CA: Multivariate Software.

Buelga S., Musitu G., Murgui S., \& Pons J. (2008). Reputation, loneliness, satisfaction with life and aggressive behavior in adolescence. The Spanish Journal of Psychology, 11, 192-200. http://dx.doi.org/10.1017/ S1138741600004236

Cava M. J., Estévez E., Buelga S., \& Musitu G. (2013). Propiedades psicométricas de la Escala de Actitudes hacia la Autoridad Institucional en adolescentes [Psychometric properties of the Adolescent Attitutudes toward Institutional Authority scale] (AAI-A). Anales de Psicología, 29, 540-548.

Cava M. J., Murgui S., \& Musitu G. (2008). Diferencias en factores de protección del consumo de sustancias en la adolescencia temprana y media [Differences in protective factors from substance abuse in early- and mid- adolescence]. Psicothema, 29, 389-395.

Cava M. J., Musitu G., Buelga S., \& Murgui S. (2010). The relationships of family and classroom environments with peer relational victimization: An analysis of their gender differences. The Spanish Journal of Psychology, 13, 156-165. http://dx.doi.org/10.1017/S1138741600003747

Cohen J. (1988). Statistical power analysis for the behavioral sciences ( $2^{\text {nd }}$ Ed.). Hillsdale, NJ: Lawrence Earlbaum Associates. DienerE., \& DienerM. (1995). Cross-cultural correlates in life satisfaction and self-esteem. JournalofPersonalityand Social Psychology, 68, 653-663. http://dx.doi.org/ 10.1037//0022-3514.68.4.653

Diener E., Emmons R. A., Larsen R. J., \& Griffin S. (1985). The Satisfaction with Life Scale. Journal of Personality Assessment, 49, 7175. http://dx.doi.org/10.1207/s15327752jpa4901_13 
Estévez E., Herrero J., \& Musitu G. (2005). El rol de la comunicación familiar y del ajuste escolar en la salud mental del adolescente [The role of family communication and school adjustment in adolescent mental health]. Salud Mental, 28, 81-89.

Expósito F., \& Moya M. C. (1999). Soledad y apoyo social [Loneliness and social support]. Revista de Psicología Social, 14, $297-316$.

Fernández-Ballesteros R., \& Sierra B. (1989). Escalas de clima social FES, WES, CIES y CES [The FES, WES, CIES and CES Social Environment Scales]. Madrid, Spain: TEA.

Garaigordobil M., \& Aliri J. (2012). Parental socialization styles, parents' educational level and sexist attitudes in adolescence. The Spanish Journal of Psychology, 15, 592-603. http://dx.doi.org/10.5209/rev_SJOP.2012.v15.n2.38870

Koepke S., \& Denissen J. J. A. (2012). Dynamics of identity development and separation - individuation in parent-child relationships during adolescence and emerging adulthood - a conceptual integration. Developmental Review, 32, 67-88. http://dx.doi.org/10.1016/j.dr.2012.01.001

Kong F., \& You X. (2013). Loneliness and self-esteem as mediators between social support and life satisfaction in late adolescence. Social Indicators Research, 110, 271-279. http://dx.doi.org/10.1007/s11205-011-9930-6

Lerner R. M. (2002). Concepts and theories of human development (3 ${ }^{\text {rd }}$ Ed.), New Jersey, NJ: Lawrence Erlbaum Associates.

Levin K. A., Dallago L., \& Currie C. (2012). The association between adolescent life satisfaction, family structure, family affluence and gender differences in parent-child communication. Social Indicators Research, 106, 287-305. http://dx.doi.org/10.1007/s11205-011-9804-y

Ma C. Q., \& Huebner E. S. (2008). Attachment relationships and adolescents' life satisfaction: Some relationships matter more to girls than boys. Psychology in the Schools, 45, 177-190.

Martín-Albo J., Nuñez J. L., Navarro J. G., \& Grijalvo F. (2007). The Rosenberg Self-esteem Scale: Translation and validation in university students. The Spanish Journal of Psychology, 10, 458-467.

Martínez-Antón M., Buelga S., \& Cava M. J. (2007). La satisfacción con la vida en la adolescencia y su relación con la autoestima y el ajuste escolar [Life satisfaction in adolescence and how it relates to self-esteem and school adjustment]. Anuario de Psicología, 38, 293-303.

Moos R. H., \& Trickett E. J. (1973). Classroom Environment Scale manual. Palo Alto, CA: Consulting Psychologist Press.

Oberle E., Schonert-Reichl K. A., \& Zumbo B. D. (2011). Life satisfaction in early adolescence: Personal, neighborhood, school, family, and peer influences. Journal of Youth and Adolescence, 40, 889-901. http://dx.doi.org/ 10.1007/s10964-010-9599-1

Parra A., \& Oliva A. (2002). Comunicación y conflicto familiar durante la adolescencia [Family communication and conflict during adolescence]. Anales de Psicología, 18, 215-231.

Proctor C. L., Linley P. A., \& Maltby J. (2009). Youth life satisfaction: A review of theliterature. Journal of Happiness Studies, 10, 583-630. http://dx.doi.org/10.1007/s10902-008-9110-9

Rosenberg M. (1989). Society and the adolescent self-image (Rev. Ed.). Middeltown, CT: Wesleyan University Press.

Russell D. W. (1996). UCLA Loneliness Scale (version 3): Reliability, validity, and factor structure. Journal of Personality Assessment, 66, 20-40. http://dx.doi.org/ 10.1207/s15327752jpa6601_2

Santos J., Muñoz A., Juez P., \& Cortiñas P. (2003). Diseño de encuestas de estudio de mercado. Técnicas de muestreo y análisis multivariante [Survey design in marketing research. Sampling techniques and multivariate analysis]. Madrid, Spain: Fundación Ramón Areces.

Stautz K., \& Cooper A. (2013). Impulsivity-related personality traits and adolescent alcohol use: A meta- analytic review. Clinical Psychology Review, 33, 574-592. http://dx.doi.org/10.1016/j.cpr.2013.03.003

Theokas C., \& Lerner R. M. (2006). Observed ecological assets in families, schools, and neighborhoods: Conceptualizations, measurement, and relations with positive and negative developmental outcomes. Applied Developmental Science, 10, 6174. http://dx.doi.org/ 10.1207/s1532480xads1002_2

Valois R. F., Zullig K. J., Huebner E. S., \& Drane J. W. (2009). Youth developmental assets and perceived life satisfaction. Is there a relationship? Applied Research on Quality of Life, 4, 315-331. http://dx.doi.org/10.1007/ s11482-009-9083-9

Valera M. R., Ávila M. E., \& Martínez B. (2013). Violencia escolar:Un análisis desde los diferentes contextos de interacción [School violence: An analysis from different interaction contexts]. Psychosocial Intervention, 22, 25-32.

http://dx.doi.org/10.5093/in2013a4 